\title{
PREPOZNAVANJE OSNOVNIH PRSTI SLOVENSKE KLASIFIKACIJE
}

\author{
dr. Blaž Repe \\ Oddelek za geografijo, Filozofska fakulteta Univerze v Ljubljani \\ Aškerčeva 2, SI-I000 Ljubljana \\ e-mail: blaz.repe@ff.uni-lj.si
}

Izvirni znanstveni članek

COBISS 1.01

\section{Izvleček}

Slovenije nikakor ne uvrščamo med pomembne kmetijske države. A vseeno v zadnjem času vedno pogosteje slišimo o čim večji samooskrbi in samozadostnosti, še posebej v povezavi z negativnimi trendi, od klimatskih sprememb, višanja cene fosilnih goriv in neobrzdanih potrebah po gradbenih površinah. Vsi, tudi geografi, imamo pogosto težave s prepoznavanjem prsti na terenu samem. V prispevku bomo skušali na preprost način prikazati metodo določevanja tipov prsti slovenske klasifikacije, osvetliti vprašanja, katere in kje so tiste naravne prsti, ki sodijo med najpomembnejše za pridelavo hrane in lokalno samooskrbo ter zahtevajo največjo stopnjo varovanja, kje so omejitve pri ostalih naravnih tipih in kako s pomočjo t.i. indikatorskih rastlin neposredno $\mathrm{v}$ pokrajini ugotavljamo nekatere najpomembnejše lastnosti prsti.

Ključne besede: klasifikacija prsti, tipi prsti, fitoindikacija, indikatorske rastline, Slovenija

\section{RECOGNITION OF THE SLOVENIAN SOIL CLASSIFICATION TYPES}

\begin{abstract}
Slovenia does not rank among the important agricultural countries. But recently, we hear more and more about self-supply and self-sufficiency, particularly in relation to all the negative trends from climate changes, fossil fuel prices rising and urban sprawl. All, including geographers, have often problems with soil identification in the field. In this article we will show a simple method of soil type determination according to Slovene soil classification, highlight issues which and where are those natural soils, the most important for food production and local self-sufficiency, and require the highest level of protection, where are restrictions on other natural soil types and how can indicator plants help in soil characteristics determination.
\end{abstract}

Key words: soil classification, soil types, phytoindication, indicator plants, Slovenia 


\section{UVOD}

Slovar slovenskega knjižnega jezika (1998) nam o klasifikaciji pove: »1. razvrstitev, razporeditev česa glede na enake ali podobne lastnosti: klasifikacija blaga; klasifikacija zemljišč/klasifikacija konj na pasme; gre za klasifikacijo dejavnosti po panogah/to ni kriterij za razredno klasifikacijo; 2 . opredelitev, uvrstitev«.

Pri klasifikaciji gre za določeno stopnjo poenostavitve, da človek zmanjša količino podatkov in stvari razvrsti v nek sistem, ki ga lažje razume ali dojame. Podobno je tudi s prstmi. Poskusi klasifikacije, vsaj neformalni, so stari toliko kot kmetijstvo. Najprej je človek razdelil prsti glede na uporabnost, torej na rodovitne in 'nerodovitne', malo ali neprimerne za kmetijstvo. Počasi je začel uporabljati tudi vidne znake, med katerimi je prevladovala barva. Prsti so bile rdeče, rumene, črne, sive itd., kar se odraža še danes (černozem, greysol, kastanozem...), tudi v naši klasifikaciji. Prsti so razvrščali še po nekaterih drugih lastnostih (kisle, peščene, plitve, težke, lahke...), rastlinstvu (tundrske, gozdne, stepske, prerijske...) ali podnebju (tropske, sredozemske, gorske...). Z Dokučajevim je stopil v veljavo genetski pristop preučevanja in tudi razvrščanja prsti. Prsti je klasificiral na podlagi razvojne stopnje oziroma geneze. V istih skupinah so prsti, ki so na enaki ali podobni razvojni stopnji. Princip se je razširil in uveljavil v celotni Evropi, kjer modificiran in prilagojen bolj ali manj velja še danes, tudi pri nas. Nasproti genetski je tehnična klasifikacija, ki temelji le na merjenih parametrih. Prsti z enakimi izbranimi lastnostmi sodijo skupaj, ne glede na razvojno stopnjo. Princip se je uveljavil v ameriški klasifikaciji, Soil Taxonomy (Lovrenčak 1994; Prus 2000; Repe 2004a).

Slovenija nima svoje uradne klasifikacije. To pomeni, da nimamo uradnega dokumenta, ki bi klasifikacijo opredeljeval ali predpisoval. Uporabljamo za slovenske razmere modificirano jugoslovansko klasifikacijo, ki ima korenine v nemški. Je pa klasifikacija znotraj stroke, vsaj na nivoju, ki bo predstavljen, dogovorjena, enotna in uveljavljena. Na njej stalno delajo in jo razvijajo slovenski pedologi (Kralj 2008). Kljub vsemu jo bomo imenovali slovenska klasifikacija prsti.

Namen prispevka je predstaviti in opisati glavne razlikovalne poudarke, na podlagi katerih lahko posamezne nivoje klasifikacije prsti prepoznamo. Izdelan in predstavljen je tudi ključ, ki omogoča dokaj preprosto določevanje prsti na terenu. Na koncu je dodano še nekaj tako imenovanih identifikacijskih rastlin, ki izrazito kažejo na lastnosti prsti in nam prav tako pomagajo pri interpretaciji in prepoznavanju.

\section{SLOVENSKA KLASIFIKACIJA PRSTI}

Osnovna enota klasifikacije je tip prsti. Sestavlja ga tipično zaporedje horizontov, kar imenujemo profil prsti. Za oznake horizontov, njihove lastnosti, procese, ki vodijo v njihov nastanek, vabim bralca $\mathrm{k}$ dodatni literaturi,saj so tam več kot zadovoljivo predstavljeni (Ćirić 1984; Škorić 1986; Stritar 1991; Lovrenčak 1994; Prus 2000; Urbančič in sod. 2005). Slovensko klasifikacijo na prvem nivoju sestavljajo 4 oddelki, ki združujejo prsti na podlagi oblik vode in njenega obnašanja. Oddelke sestavljajo razredi, kjer je odločilna geneza, torej zaporedje horizontov in njihove lastnosti. Poenostavljen profil je znotraj razreda isti za vse 
tipe, ki razred sestavljajo. Razred na koncu sestavljajo različni tipi, ki se ločijo glede na matično podlago ali prevladujoči pedogenetski proces.

Opomba: Opisane in poudarjene so razlikovalne lastnosti. Če je kakšna lastnost zelo splošna ali zelo variabilna, ne izstopa ali je enaka z nekaterimi drugimi tipi, pogosto ni predstavljena. Zaporedja horizontov so najbolj poenostavljena, kolikor se da. Nekateri tipi prsti imajo tako majhno razprostranjenost, da jih je v merilu, ki je uporabljeno, nemogoče prikazati, zato karta ni priložena. Za popoln pregled lastnosti prsti predlagam publikacijo Atlas gozdnih tal (Urbančič in sod. 2005).

\section{I. I. oddelek - AVTOMORFNE PRSTI}

- Na prsti vpliva zgolj padavinska voda, ki v nobenem delu profila niti stalno, niti občasno ne zastaja.

- Nikjer ni znakov redukcije (ni pojavljanja sive barve).

- Izjemno redko prihaja do poplav.

- Ne pojavljajo se v bližini vodotokov ali stoječih voda. Podtalnica je globoko pod površjem ali vsaj toliko, da se nikoli ne dvigne do površja.

- Večje pore so zapolnjene z zrakom, kjer poteka oksidacija železovih oksidov (rjavi odtenki), le najmanjše z vodo, ki je na voljo rastlinam.

- Pojav vlagoljubnega rastlinstva je izjema.

\subsubsection{1. razred - NERAZVITE PRSTI (zaporedje horizontov (A) - C ali (A) - R)}

- Pogosto zelo plitve, zelo mlade prsti.

- V edinem horizontu nad matično podlago je organskega gradiva le za vzorec. V njem prevladuje matična podlaga, pogosto v obliki večjih skeletnih delcev. Barva je določena $\mathrm{z}$ barvo matične podlage, ki jo organska snov malenkostno potemni.

- Humus je surov, s prepoznavnimi ostanki vejic, korenin, iglic in listov.

- Površje je zelo strmo ali razgibano.

- Rastlinstvo je največkrat pionirsko, grmovno ali zeliščno, prilagojeno na sušne pogoje.

Kamnišča (litosol). Matična podlaga je izrazito trda (v Sloveniji sta to najpogosteje apnenec ali dolomit), oziroma je bila matična podlaga zaradi naravnih ali antropogenih vzrokov nedavno izpostavljena zunanjim silam preoblikovanja. Skelet je jasno viden in ostrorob ter prevladuje. Genetsko so tipične gorske prsti.

Surove prsti (regosol). Matična podlaga je mehkejša (fliš, lapor). Skelet ni nujno ostrorob. Pogosto nastanejo na gradivu, ki je bilo sekundarno prineseno (usadi, plazovi ali antropogeno gradivo). Debelina prepereline je lahko večja. Pojavljajo se v gričevjih iz terciarnih kamnin.

Koluvialno-deluvialne prsti. Nastajajo ob vznožjih pobočij in grap, kjer se odlaga gradivo s pobočja. Značilna je mešana in nesortirana sestava večjih delcev, ki se po pobočju prikotalijo, in drobnih, ki jih prinese voda. Ker se tu delno akumulira tudi voda, gre pogosto za malo bolj vlažna rastišča javorjev, jesenov in brestov. Pojavljajo se povsod po Sloveniji v bolj ali manj širokih pasovih ob vznožjih pobočij ali v grapah. 
Slika 1: Razprostranjenost kamnišč v Sloveniji

Figure 1: Distribution of lithosols in Slovenia

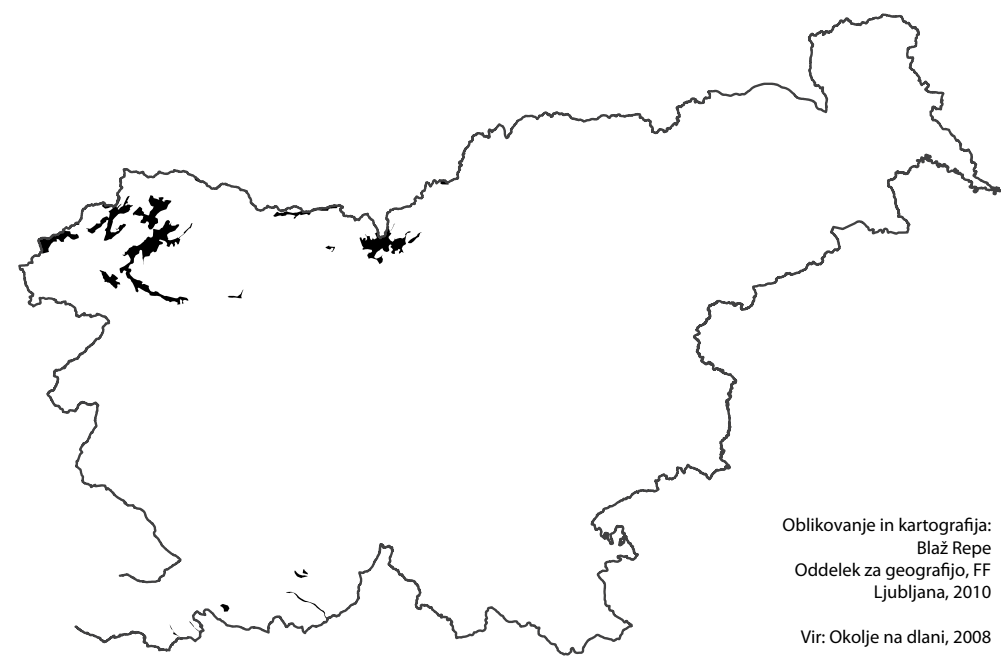

2.1.2. 2. razred - HUMUSNOAKUMULATIVNE PRSTI (zaporedje horizontov A-C ali A - R)

- Mlade, plitve prsti, redko globlje od $30 \mathrm{~cm}$.

- En sam, jasno izražen, temen, humusni horizont. V gozdu je nad njim pogosto še O horizont različno močno ali nepreperelega organskega odpada.

- Površje je največkrat nagnjeno ali razgibano, na bolj uravnanem površju gre lahko za mehkejše ali nesprijeto gradivo.

- Struktura je pogosto mrvičasta, ali vsaj kroglasta (sferična).

- Raba tal je zaradi plitvosti najpogosteje gozd ali travinja.

Rendzine. Rendzine nastanejo na vseh oblikah karbonatnih kamnin, trdih, mehkih in nesprijetih. Skeletni delci različnih oblik so praviloma prisotni. Reakcija je največkrat nevtralna do bazična. Pri določanju prostih karbonatov (preizkus s $\mathrm{HCl}$ ) dobimo očitno vidno in slišno reakcijo. Stik z matično podlago je zelo nepravilen. Predvsem zeliščna plast je bazifilna. V visokogorju, na surovem humusu, je reakcija lahko tudi izrazito kisla (pojav borovnice). Kljub pogosto dobrim kemičnim in fizikalnim lastnostim je zaradi plitvosti, skalovitosti in naklona raba tal gozd. Izrazito se navezujejo na rjave pokarbonatne prsti. So naš najbolj pogost tip prsti in se pojavljajo povsod po Sloveniji na karbonatih, v povprečju na strmejših predelih. 
Slika 2: Razprostranjenost rendzin v Sloveniji

Figure 2: Distribution of rendzic leptosols in Slovenia

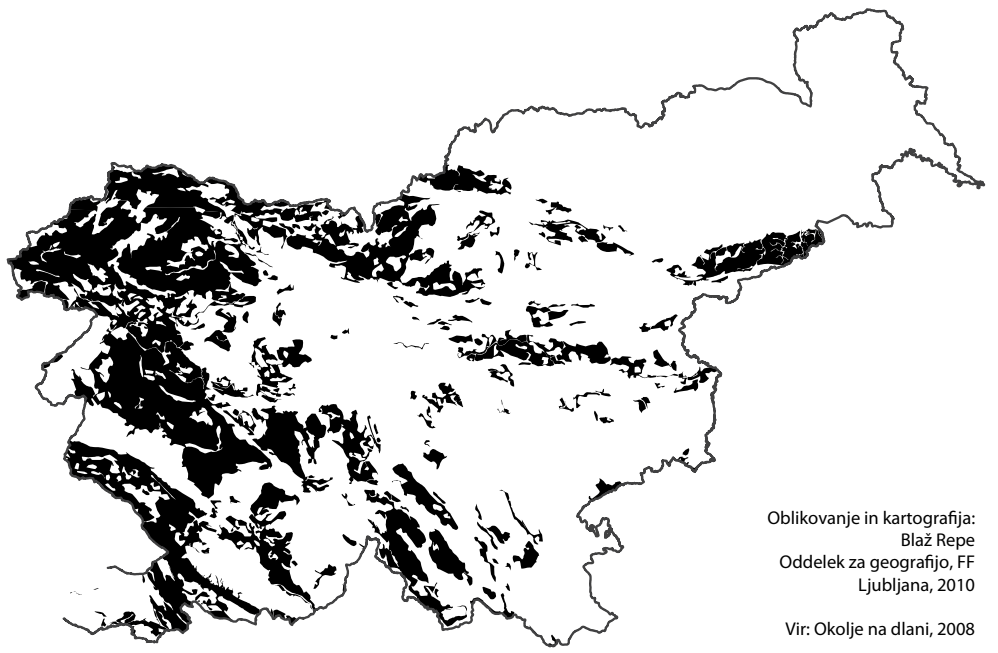

Rankerji. Rankerji nastanejo na nekarbonatnih kamninah, najpogosteje zelo trdih. Ker je teh kamnin pri nas manj (Pohorje), so pravi rankerji dokaj redki. Na sedimentnih kamninah so rankerji erozijski (profil je stanjšala vodna erozija). Močno so vezani na distrične rjave prsti. Reakcija je kisla do zelo kisla, zato je rastlinstvo kisloljubno in gozdno.

Slika 3: Razprostranjenost rankerjev v Sloveniji

Figure 3: Distribution of dystric leptosols in Slovenia

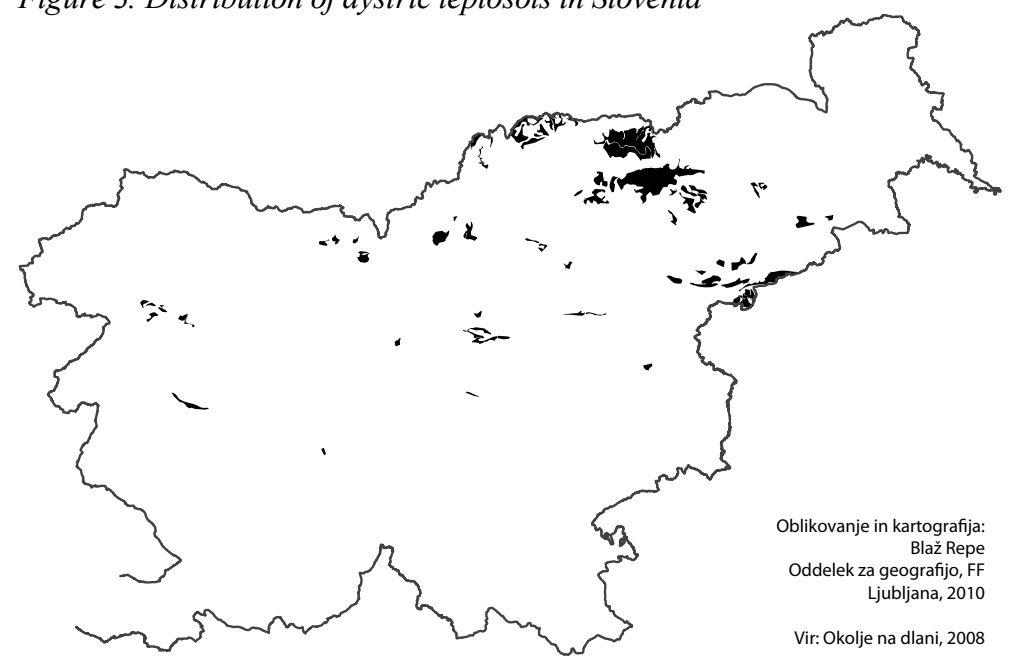




\subsubsection{3. razred - KAMBIČNE PRSTI (zaporedje horizontov A - Bv - C ali A - Brz - C)}

- Zrele prsti, vedno globlje od $30 \mathrm{~cm}$, a razen v žepih redkeje globlje od metra.

- Pojavljata se vsaj dva, jasno prepoznavna horizonta. Zgoraj je temnejši humusni A horizont. Pod njim se do matične podlage pojavlja kambični, Bv ali Brz horizont, po starem (B). Glina je posledica preperevanja matične podlage. $\mathrm{V}$ gozdu je nad njima pogosto še $\mathrm{O}$ horizont $\mathrm{z}$ različno močno ali nepreperelim organskim odpadom.

- Glaven prepoznavni znak je kambični horizont. Je mineralen, saj organsko snov lahko določimo šele v laboratoriju. Od zgornjega se loči po teksturi (v njem se izrazito poveča delež gline), strukturi (oreškasta ali poliedrična) in barvi. V našem podnebju je barva $\mathrm{v}$ odtenkih rjave, ki lahko povlečejo proti oranžni, oker ali rdeči. Na mehkejših, še posebej sedimentnih in nesprijetih vrstah matične podlage, gre za obliko Bv (preperevanje). Na trših, še posebej karbonatnih kamninah, je gradivo bodisi alohtonega porekla (prinešeno) ali ostanek prejšnjega, mehkejšega kamninskega pokrova (fliš preko apnenca). V določeni meri vsebuje tudi netopen ostanek karbonatov, zato ga še vedno označujemo z Brz.

- Raba tal je izjemno pestra: od gozda in travinja, tu je največ poseljenih površin, $v$ ta razred pa sodijo tudi naše najpomembnejše kmetijske prsti.

\section{Slika 4: Razprostranjenost evtričnih rjavih prsti v Sloveniji}

Figure 4: Distribution of eutric cambisols in Slovenia

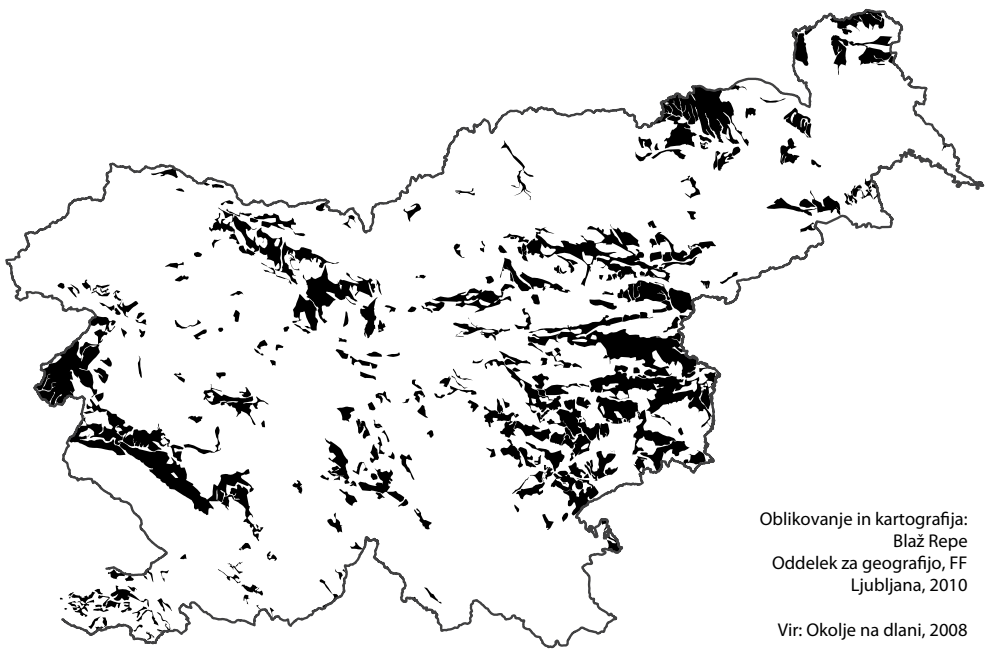

Evtrične rjave prsti. Značilne so za mehke (lapor, fliš) ali nesprijete (prod in pesek) karbonatne kamnine. Relief je blago valovit ali raven. Temeljna značilnost (določljiva le v laboratoriju) je visoka zasičenost z bazami, zunanji odraz je rahlo bazična do nevtralna reakcija in visoka primernost za kmetijstvo. A horizont je v sprsteninasti obliki, z ugodno reakcijo in mrvičasto strukturo. Kambični horizont je Bv tipa in je rjave barve. Še posebej na produ je lahko prisotno precej skeletnih delcev. Stik z matično podlago je enakomeren. Nekdaj so jih 
poraščali listnati gozdovi hrasta gradna in belega gabra, ki je ohranjen le v fragmentih. Na večini površin se pojavlja kmetijstvo, zaradi ravnega reliefa tudi ostala človekova dejavnost: poselitev, infrastruktura ali industrija. Zaradi tega konflikta so med tistimi tipi prsti, ki so najbolj na udaru. Dodatno so to v kotlinah in dolinah območja podtalnice. Pojavljajo se skupaj z rendzinami. So prsti terciarnih gričevij ter s fluvialnim in glacialnim karbonatnim prodom in peskom zasutih dolin (Vipavska, Soška in Savinjska dolina) in kotlin (Ljubljanska, Celjska...).

Distrične rjave prsti. Zelo pogost tip prsti pri nas, saj dominira v vzpetem in razgibanem, a ne preveč strmem svetu praktično na vseh nekarbonatnih, silikatnih kamninah, trdih, mehkih in nesprijetih (prod, pesek). Temeljna značilnost (določljiva le v laboratoriju) je nizka zasičenost z bazami, zunanji odraz je kisla do zelo kisla reakcija. A horizont je v prhninasti ali trhlinasti obliki, s kislim vonjem po glivah. Kambični horizont nastopa v Bv obliki in ima zaradi pomanjkanja baz slabše izraženo ter tudi slabše obstojno oreškasto strukturo. Je bolj svetlo rjavo, lahko celo rumenkasto rjavo obarvan. Prostih karbonatov ne bomo zaznali. Stik z matično podlago je enakomeren. Naravno rastlinstvo je kisloljubno in nezahtevno. Najpogosteje gre za bukove gozdove s pravim kostanjem. Kljub slabšim, predvsem kemičnim lastnostim, je kmetijstvo zaradi blažjega reliefa in agrotehničnih ukrepov pogostejše (kot pri rjavih pokarbonatnih prsteh). Pokrivajo celotno nekarbonatnao predalpsko hribovje ter ravnine in doline severovzhodne Slovenije, ki niso prekomerno vlažne.

Slika 5: Razprostranjenost distričnih rjavih prsti v Sloveniji

Figure 5: Distribution of dystric cambisols in Slovenia

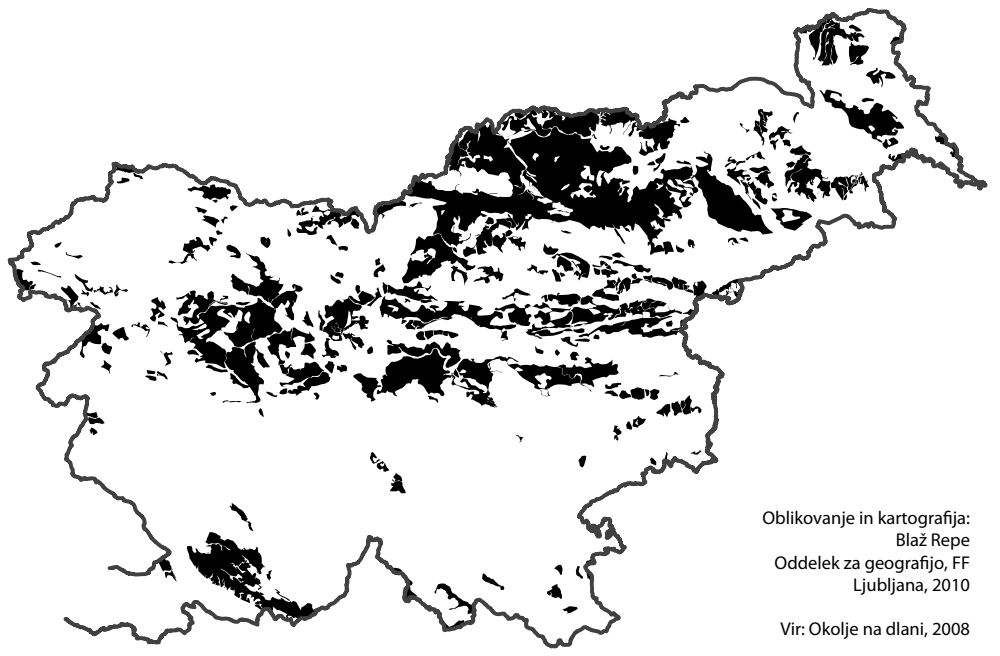

Rjave pokarbonatne prsti. Nastajajo na trdih, kompaktnih karbonatnih kamninah (apnenci in dolomiti). Relief je zelo razgiban, kraški in skalovit, brez površinskih vodnih tokov. Spadajo med naše bolj razširjene prsti. Kambični horizont je rjave barve, ki se zaradi prevlek 
železovih oksidov premaknejo proti oranžnim, rdečkastim ali rumenkastim odtenkom. Označujemo ga kot Brz zaradi prisotnosti netopnega ostanka, čeprav je glavnina gradiva vodno ali vetrno prinesenega ali pa gre za preperel ostanek mehkejšega pokrova in se je ujel v konkavne oblike (Šušteršič in sod. 2009). Struktura je pogosto izrazito poliedrična zaradi visokega deleža gline. Tekstura je težka. Kljub karbonatni podlagi je reakcija slabo kisla do kisla in se proti matični podlagi zviša. Razlog je humidna klima. Iz istega vzroka nastopa pri nas tudi izprana različica, kar bomo ugotovili z izrazitejšim višanjem reakcije z globino, v barvi horizontov tega ne bo opaziti. Stik z matično podlago je izrazito nepravilen, pravimo, da so prsti žepaste. Kljub dokaj dobrim fizikalnim in kemijskim značilnostim je raba tal v glavnem gozd (bukov), zaradi reliefa in pomanjkanja vode. Mozaično se rjave pokarbonatne prsti prepletajo z rendzinami, izpranimi prstmi in na površje štrlečimi skalami. Pojavljajo se na apnencu in dolomitu alpske, predalpske in kraške Slovenije.

\section{Slika 6: Razprostranjenost rjavih pokarbonatnih prsti v Sloveniji}

Figure 6: Distribution of chromic cambisols in Slovenia

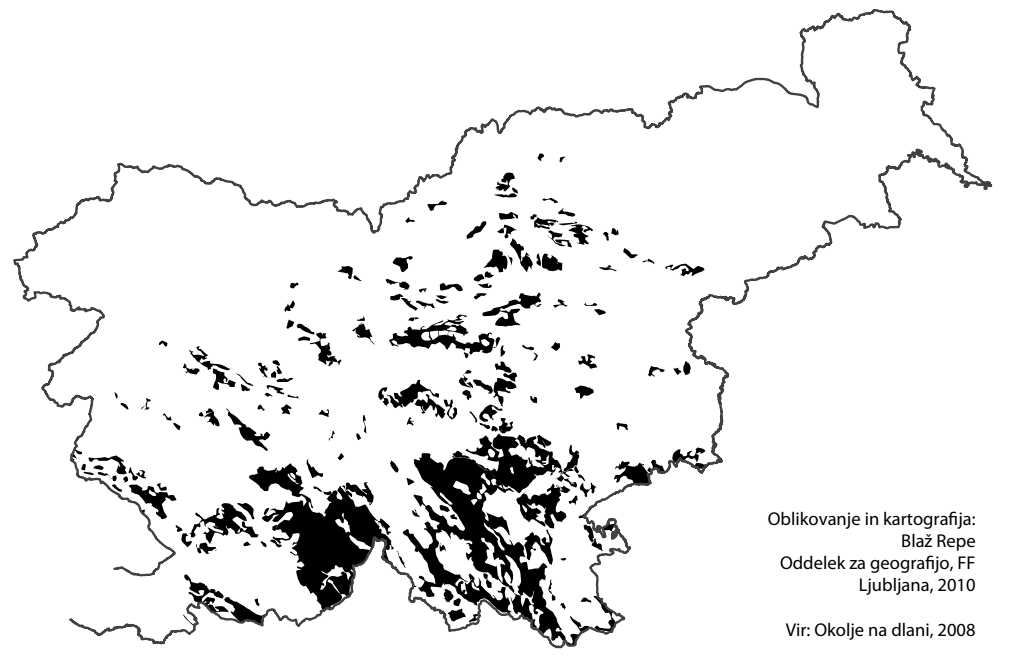

Jerovice (jerine, terra rosse). So le oblika rjavih pokarbonatnih prsti, ki so nastale na trdih apnencih in dolomitih, kjer se pojavlja submediteransko podnebje. Kambični horizont je zaradi hematita izrazito rdeče barve. Po Munsellovem barvnemu atlasu (1992) gre za odtenke bolj rdeče od 2,5 YR, kontrast/svetlost (value) in nasičenost/intenziteta (chroma) pa sta večja od 3 (Kralj 2008). Struktura je poliedrična, tekstura težka. A horizont je slabo izražen in opazen, saj organska snov zaradi tople in suhe klime hitro razpade in se mineralizira (ne nastaja humus). Zaradi dekalcifikacije prostih karbonatov ne bomo zaznali, reakcija je slabo kisla do kisla. Stik z matično podlago je izrazito neenakomeren, žepast. Imajo dobre lastnosti za uspevanje kulturnih rastlin, tipični so vinogradi in pašniki, ki pa se danes prepogosto zaraščajo. Poraščali so jih toploljubni listopadni gozdovi hrastov (puhavec), črnega gabra in malega jesena $\mathrm{z}$ jesensko vilovino v podrasti. Na Krasu je bil antropogeno nasajen črni bor. 
Kljub temu, da veljajo za tipične prsti našega Krasa (največ jerovic je prav tam), pa tam prevladujejo rendzine in rjave pokarbonatne prsti. Izrazito rdeče odtenke kambičnega horizonta bomo našli povsod po Sloveniji, poleg Krasa največ še na nizkem dolenjskem krasu in v Beli Krajini. V Sloveniji verjetno ne nastajajo več, ampak gre za reliktne prsti (ostanek pretekle, toplejše klime).

\subsubsection{4. razred - IZPRANE PRSTI (zaporedje horizontov A - E - B - C)}

- Pogosto precej globoke in v žepih lahko presegajo 2 metra.

- Trije jasno izoblikovani horizonti. Temnejšemu A horizontu sledi izpran, zelo kisel, svetlejši, teksturno lažji E horizont, z neizrazito in neobstojno strukturo. Pod njim je temnejši, rdečkast, težak, zbit in gost, močno glinast B horizont, z izrazito povišano, celo bazično reakcijo. Struktura je poliedrična in zelo obstojna. Akumulacija gline je posledica premeščanja iz zgornjega E horizonta. Razlike med E in B horizontom so jasne, vidne s prostim očesom in lahko določljive s preprostimi terenskimi preizkusi.

- Površje je uravnano, kar omogoča vertikalno pronicanje padavinske vode.

- Zaradi ravnega površja so pogosto kmetijske prsti, sicer je na njih uspeval kisloljuben gozd.

- Genetsko spadajo med naše najstarejše prsti.

Slika 7: Razprostranjenost izpranih prsti v Sloveniji

Figure 7: Distribution of haplic luvisols in Slovenia

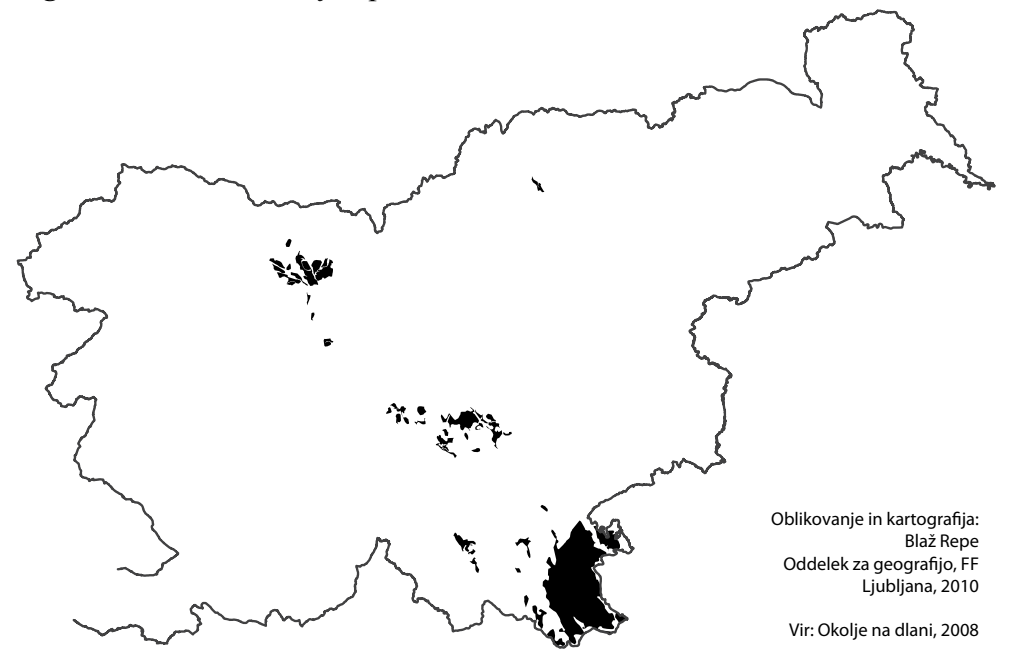

Izprane (lesivirane) prsti. Pojavljajo se na vseh matičnih podlagah in povsod po Sloveniji na uravnanem, starejšem reliefu (Stritar 1965). A horizont je zaradi kislega, igličastega odpada kisel in surov. E horizont je zelo kisel in je rumenkaste barve. Slaba struktura je posledica pomanjkanja bazičnih kationov, še posebej kalcija. B horizont ima zelo veliko železovih oksidov, zato ga označimo tudi Bfe in je temu primerno obarvan. Zaradi zbitosti včasih v 
njem zastaja padavinska voda in se lokalno lahko pojavijo znaki psevdooglejevanja (glej psevdoglej). Prostih karbonatov ne bomo zaznali. Povsod veje tipičen, kisel vonj po glivah. Kmetijske tehnike, še posebej apnenje in gnojenje, lastnosti zelo izboljšajo. Naravno tukaj uspevajo svetli, jasasti, revni in redki gozdiči rdečega bora in brez, v podrasti z borovnico, orlovo praprotjo in jesensko vreso ter ostalimi kisloljubnimi vrstami. Njihovo pojavljanje pri nas je zelo razdrobljeno in raztreseno. Največje sklenjene površine so v Beli krajini (steljniške prsti), na Koroškem ob Dravi ter na starejših terasah Ljubljanskega polja in Celjske kotline, kjer se je prod že sprejel v konglomerat.

Podzoli. Podzoli predstavljajo skrajni primer vertikalnega izpiranja in premeščanja snovi. A horizont je izrazito surov in ekstremno kisel, razpad organske snovi je izjemno počasen. Sestavljajo ga v glavnem iglice. Izprani E horizont je povsem razbarvan. Sestavljen je iz čistega kremena, zelo kisel, sivkaste ali povsem bele barve. Spodaj ležeči B horizont je gost, zbit, vlažen, tudi mazav. Vanj so bili premeščeni vsi minerali glin, bazični kationi, železovi, manganovi in aluminijevi oksidi in tudi del organske snovi. Naravno rastlinstvo je smrekov gozd $\mathrm{z}$ borovnico, brusnico in jesensko vreso $\mathrm{v}$ podrasti.

Za nastanek podzolov mora biti izpolnjenih nekaj pogojev: raven relief, hladno in vlažno podnebje, kisla silikatna podlaga (najbolje dobro prepustna peščena ali razdrobljena) in iglasto rastlinstvo, s kislim odpadom, ki padavinsko vodo še dodatno zakisa. Ker je takšna kombinacija pri nas zelo redka, so tudi podzoli pri nas izjemno redki, čeprav gre za ene najbolj razširjenih prsti severne poloble. V Sloveniji bi morali biti podzoli predmet varovanja kot naravna znamenitost na Pokljuki, Pohorju in ponekod na visokih kraških planotah.

\subsubsection{5. razred - ANTROPOGENE PRSTI (zaporedje horizontov $\mathbf{P}-\mathbf{C}$ )}

- V teh prsteh je jasno vidno delovanje človeka, kmetijstvo. Gre za odsotnost ali premešanost horizontov, nadpovrečno količino organske snovi, prekomerno založenost s hranili ali vodo, pojav naravi tujih snovi in predmetov.

- Pri nas se pojavljajo povsod, kjer je kmetijska dejavnost, pa tudi v mestnih parkih in na zelenicah.

- Ločimo dva tipa: rigolane prsti, kjer se za potrebe vinogradništva uveljavlja izrazito globoko oranje in je načeloma možno le na mehkejših kamninah, ter vrtne prsti, za katere je značilna nadpovprečno intenzivna in skrbna obdelava, s prekomernim dodajanjem organskih snovi (hlevski gnoj in kompost).

\subsubsection{6. razred - TEHNOGENE PRSTI (zaporedje horizontov I - II - III... C)}

- Gre za prsti, kjer se pojavljajo plasti, ki niso naravnega nastanka, ampak gre za nasipavanje odpadnega materiala (odpadki, jalovina, pepel...).

\subsection{II. oddelek - HIDROMORFNE PRSTI}

- Na prsti neposredno in vidno vpliva vsaj ena oblika vode, ki vsaj v delu profila občasno ali stalno zastaja.

- Očitni so znaki redukcije (sivi odtenki, ki niso posledica matične podlage) ali se v profilu pojavi velika namočenost ali celo naletimo kar na vodo samo. 
- Poplave se pojavljajo, lahko celo zelo pogosto. Tudi padavinska voda pogosto zastaja znotraj profila.

- Pojavljajo se v bližini vodotokov ali stoječih voda. Podtalnica se pogosto dvigne blizu ali celo na površje.

- Za drugi in tretji razred (za ostale manj) je značilen proces redukcije. Reducirani železovi oksidi (iz $\mathrm{Fe}^{3+} \mathrm{v} \mathrm{Fe}^{2+}$ ) so značilne sive barve (lahko tudi v zelenkastih ali modrikastih odtenkih) in prevlečejo delce gline.

- Pojavlja se vlagoljubno rastlinstvo, kar velja za vse razrede in tipe hidromorfnega oddelka.

\subsubsection{1. razred - OBREČNE PRSTI}

Slika 8: Razprostranjenost obrečnih prsti v Sloveniji

Figure 8: Distribution of fluvisols in Slovenia

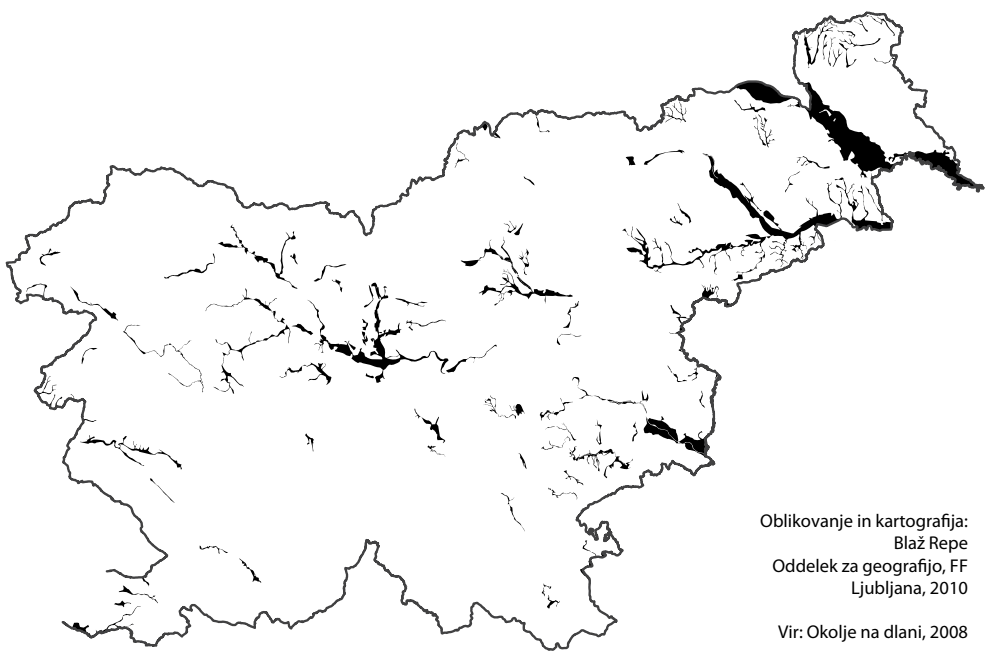

- So mlade prsti aluvialnih in poplavnih ravnic, stalno pod vplivom premikajoče se vode in dvignjene podtalnice. Bolj ko se spuščamo po vodotoku navzdol, bolj se širi vpliv vode, širši je pas teh prsti in bolj je površje ravno.

- Vodotoki stalno nanašajo novo gradivo, ki je lahko prod (zgornji tok), pesek (srednji tok), melj ali glina (spodnji tok). Veliko je skeletnih delcev.

- Če je gradivo karbonatno, je reakcija bazično nevtralna, prostih karbonatov je veliko, sicer so prsti kisle.

- V prsteh niso redke plasti, ki nastanejo z gradivom vsakoletnih poplav, vmes je plast slabo preperelega organskega gradiva. Ne smemo jih zamenjevati s horizonti, ki so genetski.

- Kljub stalni prisotnosti vode so, če je prepustnost dobra, procesi oglejevanja redki.

- Naravno uspeva pas vrbovja (bela), jelš (črna in siva), topolov (črni in beli), jesenov (veliki)... 
Nerazvite obrečne prsti (zaporedje horizontov (A) - C). Nastajajo neposredno ob vodotoku in tvorijo pogosto breg. Pogostejše so v zgornjih delih vodotokov. So zelo mlade prsti, z nerazvitim A horizontom, kjer se slabo preperelo organsko gradivo meša $\mathrm{z}$ aluvialnim, katerega zasipavanje je glavni proces. Zelo pogosto je prisotna erozija. Veliko je skeletnih delcev, preizkus s $\mathrm{HCl}$ je lahko zelo buren, če je gradivo karbonatno. Barva je v glavnem pogojena $\mathrm{z}$ barvo aluvialnega gradiva. Raba tal so pogosto travniki.

Razvite obrečne prsti (zaporedje horizontov A - C). Prevladuje drobnejše gradivo, še posebej melj in glina, zato se jih je oprijelo tudi ime rjave obrečne prsti. Praviloma se pojavljajo v uravnanem reliefu spodnjega toka rek. Vpliv vode ni tako neposreden, čeprav so poplave redne in zato vidni poplavni sloji. Imajo lahko zelo veliko humusa, so primerno zračne, z dobrimi fizikalnimi in kemičnimi lastnostmi ter lahko tudi precej globoke. Še vedno lahko vsebujejo skeletne delce. Odvisno od lastnosti gradiva so evtrične (bazične) ali distrične (kisle). Naravno je tu uspeval vlagoljubni gozd, kjer so poleg pri opisu razreda omenjenih dreves uspevali tudi hrasti (dob). Danes je veliko teh površin spremenjenih v travnike, v preteklosti pa so bile pod izjemno močnim udarom hidromelioracijskih posegov. $V$ večjih površinah se pojavljajo v spodnjem toku vseh večjih rek (Save, Savinje, Drave, Mure...).

\subsubsection{2. razred - PSEVDOOGLEJENE PRSTI (zaporedje horizontov A - Bg - C, tudi} $\mathbf{A}-\mathbf{E}-\mathbf{B g}-\mathbf{B}-\mathbf{C})$

Slika 9: Razprostranjenost psevdooglejenih prsti v Sloveniji

Figure 9: Distribution of planosols in Slovenia

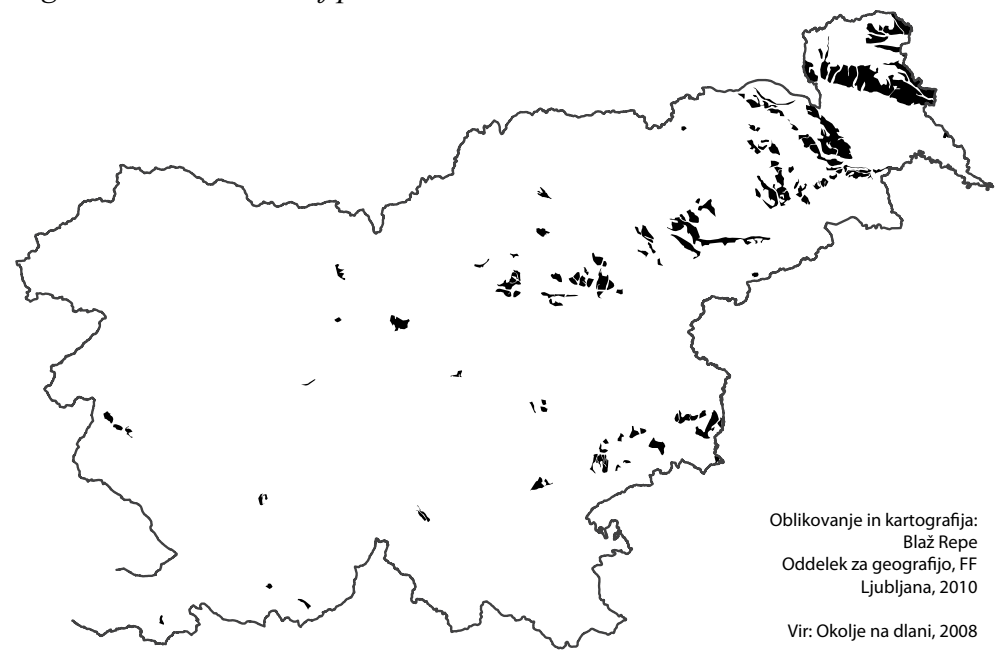

Vsebuje en sam tip: psevodooglejene prsti. So prsti, ki jim je nekje znotraj profila onemogočen nemoten odtok padavinske vode. Najpogosteje gre v ravninah za zbit, težak in gost glinast horizont, na pobočju pa je to lahko tudi neprepustna matična podlaga. Tako ločimo ravninski in pobočni psevdoglej. Padavinska voda zastaja občasno v vlažnemu delu leta, 
medtem ko se pore v sušnem delu zopet zapolnijo z zrakom. Občasno zastajanje povzroči tako imenovano marmoriranost, lisavost ali marogavost. Odvisno od prepustnosti in trajanja padavin gre lahko za sivo barvo z rjavimi lisami ali obratno. Kjer se dalj časa zadrži zrak, poteka oksidacija (rjava barva), kjer pa voda, poteka redukcija (siva barva). Podtalnica v te prsti ne seže, zato ni nikjer enotno sivega horizonta. Voda vedno prihaja od zgoraj! Naravno gre za gozdove hrasta doba, ki je v glavnem izkrčen. Za kmetijstvo so manj primerni, saj so suhi psevdogleji zelo trdi, mokri pa mazavi. Psevdogleji so v mokri fazi zelo občutljivi na delovanje človeka (zbijanje), na pobočjih jih ogroža vodna erozija prsti. Pojavljajo se povsod po Sloveniji, vendar ne tvorijo večjih sklenjenih površin. Največ jih je v severovzhodnem delu Slovenije.

\subsubsection{3. razred - OGLEJENE PRSTI ALI GLEJI (zaporedje horizontov A - Go - Gr-C)}

Slika 10: Razprostranjenost oglejenih prsti v Sloveniji

Figure 10: Distribution of gleysols in Slovenia

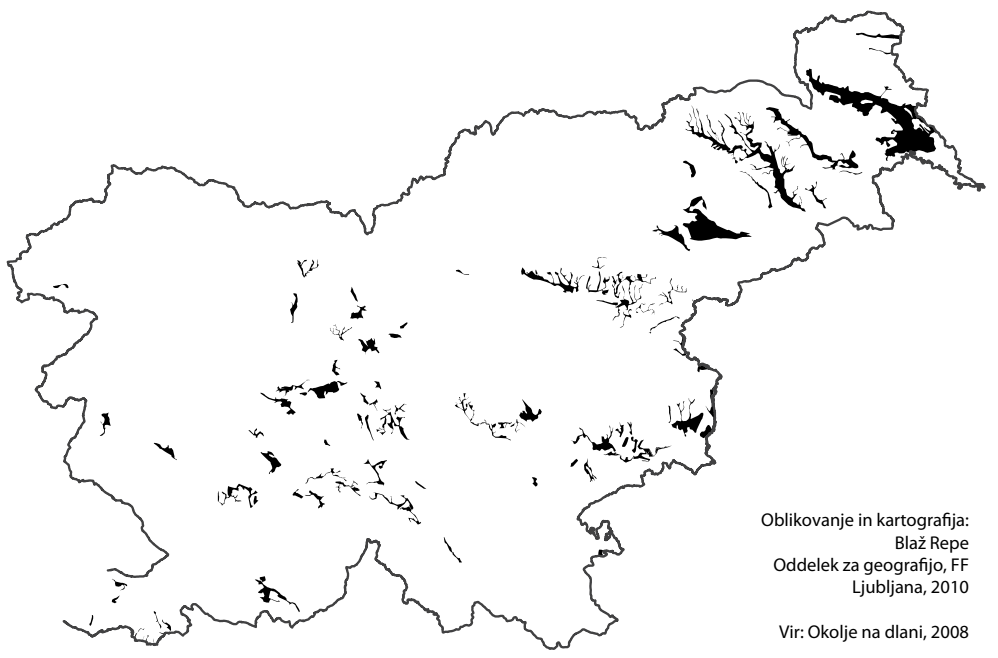

Vsebuje en sam tip: oglejene prsti. Nastajajo na izrazito ravnem reliefu, še pogosteje v konkavnih oblikah, kamor pogosto seže talna voda. Videz pokrajine je močviren. Mokrotnost dodatno povzročajo poplave. Oglejene prsti nastanejo, ker se v spodnjem delu profila stalno zadržuje talna voda. To vodi v popolno redukcijo in enotno sivo barvo redukcijskega $\mathrm{Gr}$ horizonta. Nad njim je (lahko) bolj ali manj debel marmoriran Go horizont, kjer gladina talne vode preko leta niha in prihaja do menjavanja oksidacije in redukcije. Gr horizont je izjemno glinast, težak in mazav, profil nam zaliva voda oziroma iz vzorca voda kaplja. Za Gr je značilna odsotnost strukture ali lističasta struktura. Zaradi obilice vode je organska snov v A horizontu slabo preperela. Opisane značilnosti so značilne za hipoglej, oglejene prsti pa poznajo še dve različici, in sicer epiglej, kjer gre za površinsko oglejevanje, ki ga povzroča poplavna voda, 
in amfiglej, ki je kombinacija obeh. Naravno rastlinstvo so močvirski gozdovi, predvsem črne jelše, ki so ji primešane vrbe, hrast dob in bresti. Za kmetijstvo so zelo malo primerni. V preteklosti so te površine velikopotezno osuševali, s čimer so naredili nepopravljivo škodo močvirskim gozdovom. Največ oglejenih prsti je ob Muri, Dravi, Dravinji, v spodnjem toku Save in na Ljubljanskem barju.

\subsubsection{4. razred - ŠOTNE PRSTI (zaporedje horizontov T - G ali T - C)}

Ločimo šotne prsti nizkega in visokega barja. Šotne prsti nizkega barja nastanejo v uravnanem, predvsem pa konkavnem površju, kjer talna voda stalno sega do površja. Organski odpad močvirskih trav in šašev zaradi tega ne razpade, ampak ga zajamejo anaerobni procesi, v katerih se tvori šota. Primer je Ljubljansko barje. Pri visokem barju gre za hitro rast šotnih mahov, kjer debelina šote prekine stik s podtalnico in se barje napaja le s padavinsko vodo. Podnebje je hladno in vlažno. Tu se pojavijo zelo kisle in za uspevanje rastlin zelo revne razmere. Pri nas so takšna barja pogosta na Pokljuki, Jelovici in Pohorju. Šotne prsti so izjemno občutljive na osuševanje, saj v tem primeru nakopičeno organsko gradivo zajame bliskovita mineralizacija in sproščanje $\mathrm{CO}_{2}$.

Slika 11: Razprostranjenost šotnih prsti v Sloveniji

Figure 11: Distribution of histosols in Slovenia

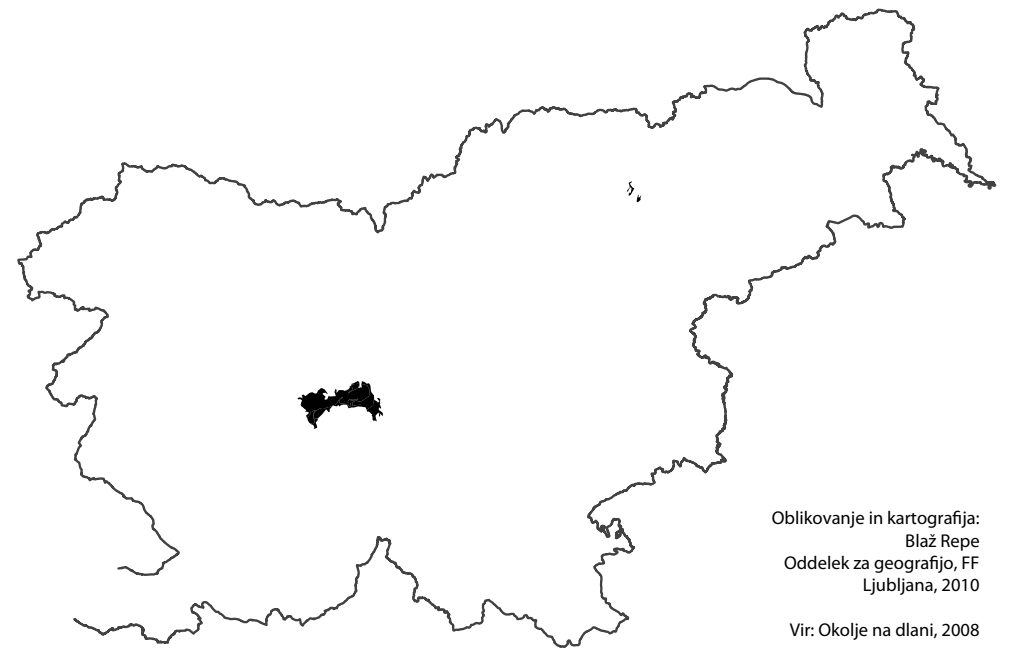

\subsubsection{5. razred - HIDROMELIORIRANE PRSTI}

Gre lahko za katerikoli tip ali razred hidromorfnega oddelka, ki je nastal z različnimi tehničnimi, predvsem hidromelioracijskimi ukrepi. Gre za različne oblike osuševanja in odvajanja vode. Danes vemo, da so ti ukrepi pogosto vprašljivi, saj ne dajo pravih rezultatov, uničijo pa mokrišča, različne močvirske habitate, šoto in poplavne gozdove. 


\subsection{III. oddelek - HALOMORFNE PRSTI}

- Na prsti ima vpliv slana voda.

- Na površini se lahko pojavlja slana skorja ali kristalčki soli (tudi globlje v profilu).

- Pojavljajo se v neposredni bližini ali ob morju (pršenje, območje bibavice), kjer se še čuti vpliv slane ali brakične talne vode. Antropogeno se pojavljajo zaradi zimskega soljenja ob prometnicah ali v urbanih območjih.

- Uspeva slanoljubno ali bazifilno rastlinstvo

- Slovensko jih imenujemo ZASLANJENE prsti; po FAO WRB klasifikaciji so to solončaki in solonci.

\subsection{IV. oddelek - SUBAKVALNE PRSTI}

- Pojavljajo se na dnu stoječih voda ali zelo počasi tekočih vodotokov.

III. in IV četrti oddelek sta v slovenskem okolju praktično neraziskana.

\section{KLJUČ ZA DOLOČANJE NARAVNIH PRSTI (brez prsti III. in IV. oddelka in antropogeno spremenjenih tipov)}

Navodilo za uporabo:

- Ključ je zelo posplošen. Namenjen je šolski in poljudni rabi za približno določevanje reprezentativnih tipov prsti slovenske klasifikacije. Za natančnejše in točno določevanje je potrebno nekaj izkušenj, večje število pripomočkov in nenazadnje tudi preverjanje v laboratoriju.

- Potrebno je osnovno znanje geografije prsti in rastlinstva ter splošna geografska razgledanost.

- Izkopan in očiščen mora biti profil prsti od površja do matične podlage/talne vode.

- Organski, O horizont je upoštevan le pri nerazvitih prsteh.

- Prepoznavanje lahko opravite tudi brez ali z minimalnim naborom terenskih pripomočkov: lopata za izkop, lopatka, indikatorski lističi, $10 \% \mathrm{HCl}$, barvni atlas.

- Odgovarjajte na vprašanja in ko (ob pravilnih odgovorih) ne morete več naprej, ste prepoznali pravi tip (odebeljena pisava). V primeru, da se vrtite v krogu, na katero od vprašanj niste odgovorili pravilno ali pa so prsti tako specifične (lastnosti preslabo izražene) ali netipične, si morate pomagati z dodatno literaturo.

Preglednica 1: Ključ za določevanje prsti slovenske klasifikacije prsti

Table 1: Key for the recognition of the Slovenian soil classification types

\begin{tabular}{|c|c|}
\hline Korak & Vprašanje \\
\hline 1. & $\begin{array}{l}\text { Ali je pokrajina pod očitnim vplivom vode? Gre za lokacijo neposredno ob vodotoku ali na } \\
\text { poplavni ravnici, z močvirnim, mokriščnim ali barjanskim videzom? Ali uspeva vodo- ali } \\
\text { vlagoljubno rastlinstvo? } \\
\text { DA } \Rightarrow \text { prsti HIDROMORFNEGA oddelka, pojdi na } 17 \\
\mathrm{NE} \Rightarrow \text { prsti AVTOMORFNEGA oddelka, pojdi na } 2\end{array}$ \\
\hline
\end{tabular}




\begin{tabular}{|c|c|}
\hline 2 & $\begin{array}{l}\text { Ali gre za en sam, slabo razvit horizont, z zelo malo organske snovi? } \\
\text { DA } \Rightarrow \text { razred NERAZVITIH prsti, pojdi na } 3 \\
\text { NE } \Rightarrow \text { pojdi na } 6\end{array}$ \\
\hline 3 & $\begin{array}{l}\text { Ali so prsti izjemno plitve, na trdi matični podlagi, ki v obliki skeleta prevladuje v profilu? Slabo } \\
\text { preperela, surova organska snov se pojavlja med skeletom? Rastlinstvo je pionirsko? } \\
\text { DA } \Rightarrow \text { KAMNIŠCE } \\
\text { NE } \Rightarrow \text { pojdi na } 4\end{array}$ \\
\hline 4 & $\begin{array}{l}\text { Ali gre za mehke kamnine z debelejšo plastjo prepereline, ki je bolje preperela in z manj } \\
\text { skeletnimi delci? Organske snovi je malo? } \\
\text { DA } \Rightarrow \text { SUROVA PRST } \\
\text { NE } \Rightarrow \text { pojdi na } 5\end{array}$ \\
\hline 5 & $\begin{array}{l}\text { Ali gre za prehod iz pobočja v uravnan del (vznožje) ali dno grape v pobočju? Gradivo profila je } \\
\text { nesortirano in očitno različnih, vseh velikosti? Na otip so prsti vlažne? } \\
\text { DA } \Rightarrow \text { KOLUVIALNO-DELUVIALNA PRST } \\
\text { NE } \Rightarrow \text { pojdi na } 1 \text { ali } 6\end{array}$ \\
\hline 6 & $\begin{array}{l}\text { Ali gre za en sam, dobro razvit in viden, temen humusni horizont? Prst ni globlja od } 30 \mathrm{~cm} ? \\
\mathrm{DA} \Rightarrow \text { razred HUMUSNOAKUMULATIVNIH prsti, pojdi na } 7 \\
\mathrm{NE} \Rightarrow \text { pojdi na } 9\end{array}$ \\
\hline 7 & $\begin{array}{l}\text { Matična podlaga je karbonatna in slušno (vidno) reagira s } \mathrm{HCl} \text { ? Prst prav tako? } \\
\text { DA } \Rightarrow \text { RENDZINA } \\
\mathrm{NE} \Rightarrow \text { pojdi na } 8\end{array}$ \\
\hline 8 & $\begin{array}{l}\text { Podlaga je trda, nekarbonatna in ne reagira s } \mathrm{HCl} \text { ? Rastlinstvo je kisloljubno? } \\
\mathrm{DA} \Rightarrow \text { RANKER } \\
\mathrm{NE} \Rightarrow \text { pojdi na } 1\end{array}$ \\
\hline 9 & $\begin{array}{l}\text { Vidna sta dva horizonta? Zgornji temnejši, humozni, in spodaj ležeči bolj glinast, z oreškasto ali } \\
\text { poliedrično strukturo? Barva spodnjega horizonta je v rjavih, oranžno rjavih, rdečkasto rjavih, } \\
\text { rumenkasto rjavih ali povsem rdečih odtenkih? } \\
\text { DA } \Rightarrow \text { razred KAMBIČNIH prsti, pojdi na } 10 \\
\text { NE } \Rightarrow \text { pojdi na } 14\end{array}$ \\
\hline 10 & $\begin{array}{l}\text { Matična podlaga je iz mehkih ali nesprijetih karbonatnih kamnin (reagira s HCl)? Reakcija je } \\
\text { nevtralna ali šibko kisla? Humusni A horizont je temen, z mrvičasto strukturo? V okolici/bližini } \\
\text { prevladuje kmetijska raba (poljedeljstvo, vinogradništvo, hmeljarstvo, sadjarstvo)? } \\
\text { DA } \Rightarrow \text { EVTRIČNA RJAVA PRST } \\
\text { NE } \Rightarrow \text { pojdi na } 11\end{array}$ \\
\hline 11 & $\begin{array}{l}\text { Matična podlaga je trd, čvrst, le mestoma prepokan apnenec ali dolomit, ki reagira s } \mathrm{HCl} \text { ? Prst } \\
\text { ima kislo reakcijo, } \mathrm{s} \mathrm{HCl} \mathrm{ne} \mathrm{reagira?} \mathrm{Prst} \mathrm{je} \mathrm{izrazito} \mathrm{in} \mathrm{očitno} \mathrm{rdeče} \mathrm{barve?} \mathrm{Ste} \mathrm{v} \mathrm{submediteranski} \\
\text { Sloveniji (Kras), nizkem dolenjskem krasu ali v Beli krajini? } \\
\text { DA } \Rightarrow \text { JEROVICA } \\
\text { NE } \Rightarrow 12\end{array}$ \\
\hline 12 & $\begin{array}{l}\text { Matična podlaga je trd, čvrst, le mestoma prepokan apnenec ali dolomit, ki reagira s } \mathrm{HCl} \text { ? Prst } \\
\text { ima slabo kislo reakcijo? Spodnji horizont je rjav, oranžno rjav ali oker? V okolici prevladuje } \\
\text { gozd? } \\
\text { DA } \Rightarrow \text { RJAVA POKARBONATNA PRST } \\
\text { NE } \Rightarrow 13\end{array}$ \\
\hline 13 & $\begin{array}{l}\text { Matična podlaga je nekarbonatna, ki s } \mathrm{HCl} \text { ne reagira? Tudi prst ne reagira s } \mathrm{HCl} \text { ? Reakcija je } \\
\text { kisla? Uspeva kisloljubno rastlinstvo? } \\
\text { DA } \Rightarrow \text { DISTRIČNA RJAVA PRST } \\
\mathrm{NE} \Rightarrow \text { pojdi na } 1 \text { ali } 14\end{array}$ \\
\hline
\end{tabular}




\begin{tabular}{|c|c|}
\hline 14 & $\begin{array}{l}\text { Vidni so vsaj } 3 \text { horizonti. Zgornji temen, kisel humusni? Pod njim svetlejši, s slabo izraženo } \\
\text { strukturo in lahko teksturo, kisel? Spodaj trd, zbit, gost, glinast, rjav horizont, z izrazito } \\
\text { poliedrično strukturo, v katerem reakcija zopet naraste? Površje je uravnano? Uspeva nezahtevno, } \\
\text { pionirsko in kisloljubno rastlinstvo? } \\
\text { DA } \Rightarrow \text { razred IZPRANIH prsti, pojdi na } 15 \\
\mathrm{NE} \Rightarrow \text { pojdi na } 1\end{array}$ \\
\hline 15 & $\begin{array}{l}\text { Podnebje je hladno, vlažno (gorsko)? Srednji, izpran E horizont je siv ali bel? Reakcija je } \\
\text { ekstremno kisla? Humusni horizont je surov in 'smrdi’ po glivah? Prevladujejo iglavci (smreka)? } \\
\text { Uspevata borovnica ali brusnica? } \\
\text { DA } \Rightarrow \text { PODZOL } \\
\mathrm{NE} \Rightarrow \text { pojdi na } 16\end{array}$ \\
\hline 16 & $\begin{array}{l}\text { Srednji, izpran E horizont je svetlo rjav, rumenkast? Podnebje je zmerno? Uspevajo rdeči bor, } \\
\text { breza, orlova praprot, borovnica? } \\
\text { DA } \Rightarrow \text { IZPRANA PRST (v ožjem pomenu) } \\
\text { NE } \Rightarrow \text { pojdi na } 1\end{array}$ \\
\hline 17 & $\begin{array}{l}\text { Ste na poplavni/aluvialni ravnici, zelo blizu ali ob vodotoku? Raba tal je poplavni gozd ali } \\
\text { travnik? Profil vam ne zaliva talna voda? Nikjer ni znakov redukcije (enotna siva barva, ki ni } \\
\text { posledica matične podlage)? } \\
\text { DA } \Rightarrow \text { razred OBREČNIH prsti, pojdi na } 18 \\
\mathrm{NE} \Rightarrow \text { pojdi na } 20\end{array}$ \\
\hline 18 & $\begin{array}{l}\text { Prsti so skeletne? Organska snov je le med skeletnimi delci? Vidni so znaki vsakoletnih poplav } \\
\text { (trava in plastične vrečke v vejah drevja)? Vidno je zasipavanje z gradivom in obenem erozijski } \\
\text { procesi? Rastlinstvo je obvodno (vrbe, jelše, topoli)? } \\
\text { DA } \Rightarrow \text { NERAZVITA OBREČNA PRST } \\
\text { NE } \Rightarrow \text { pojdi na } 19\end{array}$ \\
\hline 19 & $\begin{array}{l}\text { Ste na aluvialni ravnici? Prst je sorazmerno globoka? Prevladuje drobnejše gradivo (melj, glina)? } \\
\text { Površje je uravnano? Še vedno so prisotni skeletni delci? Humusni horizont je dobro razvit, } \\
\text { jasno viden in rjave barve? Lahko so vidni sloji občasnih poplav (menjavanje slojev)? Uspeva } \\
\text { vlagoljubno rastlinstvo (hrast dob, veliki jesen, vrbe, topoli)? } \\
\text { DA } \Rightarrow \text { RAZVITA OBREČNA PRST } \\
\text { NE } \Rightarrow \text { pojdi na } 20\end{array}$ \\
\hline 20 & $\begin{array}{l}\text { Površje je uravnano, celo konkavno (ravnina), z močvirskim videzom? Matična podlaga je } \\
\text { nesprijeta, glinasta? Profil vam spodaj zaliva voda ali pa je izjemno moker? Spodnji horizont je } \\
\text { ekstremno glinast, lepljiv, mazav, moker in povsem sive barve, brez ali z lističasto strukturo? } \\
\text { Uspeva črna jelša in vrbe, kalužnica, bički, ločje...? } \\
\text { DA } \Rightarrow \text { OGLEJENA PRST } \\
\text { NE } \Rightarrow 21\end{array}$ \\
\hline 21 & $\begin{array}{l}\text { V profilu se pojavi LE marmorian, lisast ali marogast horizont, siv } \mathrm{z} \text { očitnimi rjavimi lisami ali } \\
\text { obratno, rjav s sivimi lisami, ki NE preide v enotno siv redukcijski horizont? } \\
\text { DA } \Rightarrow \text { PSEVDOOGLEJENA PRST } \\
\mathrm{NE} \Rightarrow \text { pojdi na } 22\end{array}$ \\
\hline 22 & $\begin{array}{l}\text { Površje je uravnano? Pokrajina ima videz mokrišča? Ob prehodu vam stopinje in čevlje zaliva } \\
\text { voda? Pojavlja se šota (mehak korak; če skočite, se okolica trese)? } \\
\text { DA } \Rightarrow \text { razred ŠOTNIH prsti, pojdi na } 23 \\
\text { NE } \Rightarrow \text { pojdi na } 1\end{array}$ \\
\hline 23 & $\begin{array}{l}\text { Pojavljajo se površinski vodotoki, ki poplavljajo? Uspevajo trave in šaši, mahov pa je malo? } \\
\text { DA } \Rightarrow \text { ŠOTNE PRSTI NIZKEGA BARJA } \\
\text { NE } \Rightarrow \text { pojdi na } 24\end{array}$ \\
\hline 24 & $\begin{array}{l}\text { Podnebje je hladno in gorsko? Ni površinskih vodnih tokov? Uspevajo šotni mahovi? } \\
\text { DA } \Rightarrow \text { ŚOTNE PRSTI VISOKEGA BARJA } \\
\text { NE } \Rightarrow \text { pojdi na } 1\end{array}$ \\
\hline
\end{tabular}




\section{INDIKATORSKE RASTLINE}

Med dejavniki okolja in rastlinami, še posebej skupinami (združbe), obstajajo določene povezave. Če poznamo zahteve določene rastline za rast, njeno uspevanje na neki lokaciji pove, da morajo biti tam zanjo približno ugodni pogoji. Če so rastline ozko specializirane in imajo nizko toleranco za spremembe (stenotopnost, stenovalentnost), je povezava še toliko bolj očitna in jasna. Takšne rastline, ki s svojim pojavom kažejo na tipične lastnosti okolja, imenujemo indikatorji oziroma fitoindikatorji ali rastlinski indikatorji. Veliko vrednost, katera od-raža ekološko naravnanost rastline, imajo tiste z ozkim območjem pojavljanja, npr. izrazito sušna oz. vlažna prst. Te vezane rastline, ki uspevajo na izključno prsteh s svojo morfološko, fizikalno, kemično, biološko, vodno - zračno lastnostjo, imajo nekakšno nakazovalno vlogo določenega dejavnika.

Veliko bolj zanesljivo informacijo o stanju okolja kot posamezne rastline nam dajo skupine rastlin, ki se hkrati pojavljajo na določenem mestu, saj tako lahko brez vsakršnih posegov v okolje z večjo gotovostjo sklepamo o rastiščnih razmerah (Urbančič in sod. 2005). Najbolj razširjene takšne združbe v Sloveniji so: združbe črne jelše (Alnetum glutinosae), ki se pojavljajo na mokrotnih rastiščih in ob vodotokih; na apnenčasti podlagi uspevajo združbe bukve in navadnega tevja (Hacquetio-Fagetum) ter bukve in spomladanske torilnice (Omphalodo-Fagetum); združbe puhavca in črnega gabra (Ostryo carpinifoliae-Quercetum pubescentis) v izrazito toplotnih razmerah; združbe bukve in rebrenjače (Blechno-Fagetum) pa na kislih prsteh (Repe 2004b).

Pri vsem tem so nam v veliko pomoč metode, katerih osnova je ekološko vrednotenje vsake posamezne vrste glede na okoljske dejavnike. Njihove indikacijske vrednosti so števila, ki izražajo ekološko naravnanost posamezne rastline. Prvi, ki se je s tem ukvarjal, je bil Iversen, ki je odziv rastlin opredelil na relativni lestvici. Leta 1936 je določil indikacijske vrednosti glede na slanost. Kasneje so se s tem ukvarjali evropski avtorji, npr. Ambros, Ellenberg, Ehrendorfer, Karre, Landlot, Soo, Zolyomi (Urbančič in sod. 2005). V Sloveniji je na tem področju deloval Živko Košir.

Metode razvrščanja fitoindikatorjev glede na navezanost določenih razmer v prsti so tudi pomanjkljive. Vzrok je iskati v geografski omejenosti, saj se indikatorska vloga posamezne rastline razlikuje znotraj območja njene razširjenosti. Poleg navedenega pa se iste rastline istega geografskega areala lahko pojavljajo na različnih matičnih podlagah, kar je lahko povezano $\mathrm{z}$ drugačnimi okoljskimi dejavniki in $\mathrm{s}$ tem tudi $\mathrm{z}$ drugačno rastlinsko kombinacijo. Zaradi tega se moramo pri uporabi metod seznaniti z uporabljenim geografskim območjem, saj moramo vedeti, pod kakšnimi pogoji so te nastale.

Najbolj razširjena in splošno znana je Ellenbergova fitoindikacijska metoda, sestavljena na podlagi posameznega dejavnika, ki vpliva na vrednosti rastlinske lestvice. Zavzema tudi povprečne ekološke razmere v združbi, katere predstavljajo povprečje bioindikacijskih vrednosti za vse rastline glede na določen dejavnik. V svoji metodi je zajel 2726 vrst praprotnic in semenk. Vključene so tako gozdne kot negozdne fitocenoze ter vegetacija agrarnih kultur, vodnih in halogenih fitocenoz (Accetto, 2001; Urbančič in sod. 2005).

Ekološki dejavniki, na podlagi katerih je opredeljena Ellenbergova metoda, so: svetlobne razmere $(\mathrm{L}-$ Lichtzahl $)$, toplotne razmere $(\mathrm{T}-$ Temperaturzahl), kontinentalnost $(\mathrm{K}-$ Konti- 
nentalitätszahl), vlažnostne razmere ( $\mathrm{F}$ - Feuchtezahl), reakcija prsti ( $\mathrm{R}$ - Reaktionszahl) in potrebe po dušiku (N - Stickstoffzahl) (Ökologische Zeigerwerte 2010). Večina rastlinskih vrst je izražena v devetstopenjski lestvici, v kateri stopnja 1 pomeni najmanjšo in stopnja 9 največjo mero določenega dejavnika, le vlažnost je izražena v dvanajststopenjski lestvici.

Predstavljenih bo nekaj izbranih rastlinskih predstavnikov z obeh skrajnih koncev tabele, ki najbolj ozko nakazujejo rastiščne pogoje in so praktično zanesljivi pokazatelji razmer na neki lokaciji. Upoštevati je potrebno, da gre za naravno rastišče, brez vpliva človeka.

\section{I. Indikacija svetlobnih razmer (L/S)}

Evhkiofiti, rastline popolne sence in skiofiti, rastline sence: navadna zajčja deteljica (Oxalis acetosella), čemaž (Allium ursinum), dlakava bekica (Luzula pilosa), trpežni golšec (Mercurialis perennis), rjava gnezdovnica (Neottia nidus avis), mnogocvetni salomonov pečat (Polygonatum multiflorum), bela jelka (Abies alba), trilistna vetrnica (Anemone trifolia), navadni kopitnik (Asarum europaeum), podlesna vetrnica (Anemone nemorosa)...

Heliofiti, rastline svetlobe in evheliofiti, rastline popolne osvetljenosti: sibirski brin ( $\mathrm{Ju}$ niperus sibirica), topokrpi javor (Acer obtusatum), navadni brin (Juniperus communis), evropski macesen (Larix decidua), rušje (Pinus mugo), drobnica (Pyrus pyraster), navadni šipek (Rosa canina), rdeča vrba (Salix purpurea), jesenska vresa (Calluna vulgaris), cipresasti mleček (Euphorbia cyparissias)...

\subsection{Indikacija toplotnih razmer ( $T$ )}

Indikatorji mrzlih razmer, kakršne vladajo v alpinskem pasu in rastline, ki nakazujejo hladne razmere subalpinskega pasu: cemprin (Pinus cembra), sibirski brin (Juniperus sibirica), čvrsti šaš (Carex firma), zavešček (Neckera crispa), planinski srobot (Clematis alpina), modro kosteničevje (Lonicera caerulea), navadna smreka (Picea abies)...

Indikatorji submediteranskih toplotnih razmer in skrajno toplih razmer: črnika (Quercus ilex), etrursko kosteničevje (Lonicera etrusca), črni gaber (Ostrya carpinifolia), skorš (Sorbus domestica), mali jesen (Fraxinus ornus), trokrpi javor (Acer monspessulanum), cer (Quercus cerris), navadni ruj (Cotinus coggygria), puhavec (Quercus pubescens), navadni jesenček (Dictamnus albus), brek (Sorbus torminalis), poljski brest (Ulmus minor), rumeni dren (Cornus mas), črni bor (Pinus nigra), rešeljika (Prunus mahaleb)...

\subsection{Indikacija kontinentalnosti podnebja (K)}

Evoceanske vrste in rastline oceanske ter zahodne Evrope: črnika (Quercus ilex), navadni pušpan (Buxus sempervirens), pravi kostanj (Castanea sativa), navadni oreh (Juglans regia), navadni zimzelen (Vinca minor), graden (Quercus petraea), dišeča lakota (Galium odoratum), navadni bršljan (Hedera helix)...

indikatorji celinskih razmer, kakršne vladajo vzhodneje od Srednje Evrope in prave kontinentalne (evkontinentalne) vrst: bradavičasta trdoleska (Euonymus verrucosa), beli topol (Populus alba), beka (Salix viminalis), beli šaš (Carex alba), planinski srobot (Clematis al- 
pina), modro kosteničevje (Lonicera caerulea), cemprin (Pinus cembra), sibirski brin (Juniperus sibirica), rdeči bor (Pinus sylvestris)...

\subsection{Indikacija vlažnostnih razmer (F/V)}

Indikatorji skrajno sušnih razmer in nakazovalke sušnih razmer, ki jih včasih najdemo tudi na sveži, nikoli pa ne na vlažni podlagi: gorski vrednik (Teucrium montanum), mali jesen (Fraxinus ornus), trokrpi javor (Acer monspessulanum), navadni ruj (Cotinus coggygria), puhavec (Quercus pubescens), navadni jesenček (Dictamnus albus), črni bor (Pinus nigra), rešeljika (Prunus mahaleb), krvavo rdeča krvomočnica (Geranium sanguineum), šmarna hrušica (Amelanchier ovalis), cipresasti mleček (Euphorbia cyparissias), navadni nagnoj (Laburnum anagyroides), spomladanska resa (Erica carnea), pozidna rutica (Asplenium ruta-muraria), črnika (Quercus ilex), etrursko kosteničevje (Lonicera etrusca)...

Indikatorji mokrih razmer (rastline, ki imajo težišče razprostranjenosti na premočeni, pogosto slabo prezračeni podlagi) in rastline, ki brez večje škode prenesejo daljša obdobja, ko podlaga ni zalita z vodo: pepelnatosiva vrba (Salix cinerea), vodna perunika (Iris pseudacorus), črna jelša (Alnus glutinosa), črni topol (Populus nigra), bela vrba (Salix alba), dolgopecljati brest (Ulmus laevis), navadna krhlika (Frangula alnus), logarica (Fritillaria meleagris), čremsa (Prunus padus), rakita (Salix aurita), navadni repuh (Petasites hybridus), puhasta breza (Betula pubescens), beli topol (Populus alba), siva jelša (Alnus incana), gola vrba (Salix glabra), velecvetna mrtva kopriva (Lamium orvala), navadna podborka (Athyrium filix-femina), rušnata masnica (Deschampsia caespitosa)...

\subsection{Indikacija kemične reakcije podlage (R)}

Indikatorji zelo kisle podlage; rastline, ki jih nikoli ne najdemo na slabo kisli ali alkalni podlagi: beli mah (Leucobryum glaucum), jesenska vresa (Calluna vulgaris), modro kosteničevje (Lonicera caerulea), viličasti mah (Bazzania trilobata), rebrenjača (Blechnum spicant), brusnica (Vaccinium vitis-idaea), borovnica (Vaccinium myrtillus), dlakava košeničica (Genista pilosa), vijugasta masnica (Avenella flexuosa), puhasta breza (Betula pubescens), dvolistna senčnica (Maianthemum bifolium), belkasta bekica (Luzula luzuloides), orlova praprot (Pteridium aquilinum), navadna krhlika (Frangula alnus)...

Nakazovalke bazične reakcije ali zelo karbonatne podlage: navadna ciklama (Cyclamen purpurascens), črni bor (Pinus nigra), beli topol (Populus alba), siva jelša (Alnus incana), gola vrba (Salix glabra), planinsko kosteničevje (Lonicera alpigena), goli lepen (Adenostyles alpina), velikolistna vrba (Salix appendiculata), zeleni sršaj (Asplenium viride), navadni pljučnik (Pulmonaria officinalis), navadna hruška (Pyrus communis), širokolistna trdoleska (Euonymus latifolia), črni teloh (Helleborus niger), mandljevolistni mleček (Euphorbia amygdaloides), navadni ženikelj (Sanicula europaea), navadna trdoleska (Euonymus europaea), jelenov jezik (Phyllitis scolopendrium), volčja češnja (Atropa belladonna), čistilna krhlika (Rhamnus catharticus), skorš (Sorbus domestica), rumeni dren (Cornus mas), kovačnik (Lonicera caprifolium), navadno tevje (Hacquetia epipactis), navadni češmin (Berberis vulgaris), navadna kalina (Ligustrum vulgare), enovrati glog (Crataegus monogyna), navadni pušpan 
(Buxus sempervirens), dobrovita (Viburnum lantana), mali jesen (Fraxinus ornus), trokrpi javor (Acer monspessulanum), navadni jesenček (Dictamnus albus), rešeljika (Prunus mahaleb), krvavo rdeča krvomočnica (Geranium sanguineum), navadni nagnoj (Laburnum anagyroides)...

\subsection{Indikacija preskrbljenosti prsti z dušičnimi spojinami (N)}

Indikatorji najslabše preskrbljenosti podlage z dušikom: brusnica (Vaccinium vitis-idaea), jesenska vresa (Calluna vulgaris), črni bor (Pinus nigra), kovačnik (Lonicera caprifolium), navadni jesenček (Dictamnus albus), rešeljika (Prunus mahaleb), sibirski brin (Juniperus sibirica), divji nageljček (Dianthus sylvestris), modro kosteničevje (Lonicera caerulea), dlakava relika (Chamaecytisus hirsutus), spomladanska resa (Erica carnea), trstikasta stožka (Molinia arundinacea)...

Nakazovalke pretirane založenosti z dušičnimi spojinami; predstavniki stajskega in smetiščnega rastlinja: črni bezeg (Sambucus nigra), volčja češnja (Atropa belladonna), navadni repuh (Petasites hybridus), pegasti kačnik (Arum maculatum), trpežna srebrenka (Lunaria rediviva), spomladanski veliki zvonček (Leucojum vernum), čemaž (Allium ursinum), velika kopriva (Urtica dioica), divji bezeg (Sambucus racemosa), navadno kresničevje (Aruncus dioicus), dlakavi lepen (Adenostyles alliariae), robinija (Robinia pseudoacacia), bela vrba (Salix alba), trpežni golšec (Mercurialis perennis), črni topol (Populus nigra), dolgopecljati brest (Ulmus laevis), mali zvonček (Galanthus nivalis), volčja jagoda (Paris quadrifolia), goli brest (Ulmus glabra), iva (Salix caprea), navadni oreh (Juglans regia), deveterolistna konopnica (Dentaria enneaphyllos), navadni srobot (Clematis vitalba), veliki jesen (Fraxinus excelsior), velecvetna mrtva kopriva (Lamium orvala), navadna lipa (Tilia platyphyllos)... (Ellenberg in sod. 1991; Accetto in Robič 1999; Ökologische Zeigerwerte 2008).

\section{SKLEP}

Ko danes trgujemo s prostorom za naše udejstvovanje v družbi, dejansko trgujemo tudi z zemljišči oziroma zemljo. Vrednosti prostora se zelo dobro zavedamo. Vendar ko zemljišče s prstjo vred pride enkrat v kremplje kapitala, se do njega začnemo naenkrat obnašati, kot smo se do vode in zraka še v prejšnjem stoletju. S prstjo počnemo, kar nam je volja, postane privatna lastnina. Prst dejansko ne predstavlja nobene vrednosti, ceno ima le prostor. Po drugi strani pa smo na zemljo prav bolestno navezani. Koliko več smo pripravljeni odšteti za nadstandardni zeleni pas v bivalni okolici ali celo mini vrtiček. Sanje praktično vsakega Slovenca je hiša z vrtom, kjer se z nagonsko zavzetostjo ukvarjamo z enim najbolj prvinskih človekovih opravil. Pridelava hrane pomeni ohranitev vrste. To dvojno obnašanje je zelo presenetljivo. Če smo vodo in zrak jemali kot samoumevno in smo se njunih vrednosti dejansko ovedli šele pred kratkim, pa je vrednost 'zemlje' nedvoumno prisotna v naši zavesti od samega obstoja človeštva. Še celo svoj planet smo poimenovali Zemlja. Ne Voda in ne Zrak.

Slovenije nikakor ne uvrščamo med pomembne kmetijske države. A vseeno v zadnjem času vedno pogosteje slišimo o čim večji samooskrbi in samozadostnosti, še posebej v povezavi z vsemi negativnimi trendi, od klimatskih sprememb, višanja cene fosilnih goriv in 
neobrzdanih potrebah po gradbenih površinah. Za geografa je nujno, da pozna pokrajino okoli sebe in s tem tudi prsti in rastlinstvo, kar mu omogoča odgovoriti na premnoga vprašanja o stanju in procesih. Vendar je preučevanje prsti in rastlinstva neposredno na terenu izjemno zamudno, fizično naporno, strokovno in finančno zahtevno in časovno zamudno. Marsikdaj se srečamo pred dilemo, kaj vidimo ob izkopani profilni jami in kako informacije povezati v smiselno celoto, ki ji rečemo tip prsti. Omenjeni prispevek skuša na preprost način prikazati metodo določevanja tipov prsti slovenske klasifikacije, osvetliti vprašanja, katere in kje so tiste naravne prsti, ki sodijo med najpomembnejše za pridelavo hrane in lokalno samooskrbo ter zahtevajo največjo stopnjo varovanja, kje so omejitve pri ostalih naravnih tipih, kako s pomočjo t.i. indikatorskih rastlin neposredno v pokrajini ugotavljamo nekatere najpomembnejše lastnosti prsti. Za izpolnitev teh potreb je bil izdelan tudi preprost določevalni ključ.

\section{Viri in literatura}

Accetto, M. 2001: Opis pomembnejših gozdnih združb v Sloveniji (prirejeno za študente rednega in izrednega visokošolskega strokovnega in univerzitetnega študija gozdarstva ter univerzitetnega študija krajinske arhitekture). Oddelek za gozdarstvo in obnovljive vire, Biotehniška fakulteta Univerze v Ljubljani, 64 str. Ljubljana.

Accetto, M., Robič, D. 1999: Gradivo za pouk fitocenologije. Oddelek za gozdarstvo, Biotehniška fakulteta Univerza v Ljubljani. Ljubljana.

Čarni, A., Marinček, L. 2002: Komentar k vegetacijski karti gozdnih združb Slovenije v merilu 1:400 000. Biološki inštitut Jovana Hadžija ZRC SAZU. Založba ZRC, 79 str. Ljubljana.

Ćirič, M. 1984: Pedologija. 1. izdanje. SOUR Svjetlost. 331 str. Sarajevo.

Ellenberg, H., Weber, H. E., Doll, R., Wirth, V., Werner, W. 1991. Zeigerwerte von Pflanzen in Mitteleuropa. Scripta geobotanica 18. Lehrstuhl für Geobotanik der Universität Göttingen 18, 247 str. Göttingen.

Kralj, T. 2008: Primerjava sistemov za razvrščanje tal na izbranih tleh v Sloveniji. Doktorska disertacija. Oddelek za agronomijo, Biotehniška fakulteta Univerze v Ljubljani. 413 str. Ljubljana.

Lovrenčak, F. 1994: Pedogeografija. Oddelek za geografijo, Filozofska fakulteta Univerze v Ljubljani. 187 str. Ljubljana.

Munsell Soil Color Charts 1992.

Okolje na dlani 2008: http://nfp-si.eionet.europa.eu/News/NEWS1203675146/Dokumenti/ pdf/OND07/OND1_znacil.pdf (1.3.2008).

Ökologische Zeigerwerte 2008: http://statedv.boku.ac.at/zeigerwerte/ (22. 9. 2010).

Prus, T. 2000: Klasifikacija tal. Študijsko gradivo za ciklus predavanj 2000 (spletno gradivo: http://www.bf.uni-lj.si/cpvo/Novo/PDFs/KlasifikacijaTal.pdf (7. 6. 2004). Center za pedologijo in varstvo okolja, Biotehniška fakulteta Univerze v Ljubljani.

Repe, B. 2004a: Soils of Slovenia. Slovenia - A geographical overview. Zveza geografskih društev Slovenije. Založba ZRC, str. 51-56. Ljubljana.

Repe, B. 2004b: Vegetation of Slovenia. Slovenia - A geographical overview. Zveza geografskih društev Slovenije. Založba ZRC, str. 57-62. Ljubljana. 
Seznam pedosistemskih enot, 1995: Pedološka karta Slovenije. Center za pedologijo in varstvo okolja, Oddelek za agronomijo, Biotehniška fakulteta Univerze v Ljubljani. Ljubljana.

Slovar slovenskega knjižnega jezika 1998: DZS d.d., elektronska izdaja: Amebis d.o.o.

Stepančič, D., Lobnik, F., Prus, T., Kalan, J., Vidic, J. N., Kajfež-Bogataj, L., Zupančič, M., Seliškar, A., Stritar, A., Šrok, D. 1986: Osnovna pedološka karta SFRJ 1:50.000 (Ljubljana, Ptuj, Murska Sobota) s komentarji. Geodetski zavod Slovenije in Katedra za pedologijo, prehrano rastlin in ekologijo, Biotehniška fakulteta Univerze v Ljubljani. Ljubljana.

Stritar, A. 1965: Značilna zaporedja talnih oblik v Sloveniji. Geografski obzornik 12, 3. Ljubljana.

Stritar, A. 1991: Pedologija (kompendij). Biotehniška fakulteta, 122 str. Ljubljana.

Škorić, A. 1986: Postanak, razvoj i sistematika tla. Sveučilište u Zagrebu, 172 str. Zagreb.

Šušteršič, F., Rejšek, K., Mišič, M., Eichler, F. 2009: The role of loamy sediment (terra rossa) in the context of steady karst lowering. V: Geomorphology 106, 1-2, str. 34-45. Amsterdam.

Urbančič, M., Simončič, P., Prus, T., Kutnar, L. 2005: Atlas gozdnih tal Slovenije. Zveza gozdarskih društev Slovenije, Gozdarski vestnik in Gozdarski inštitut Slovenije,100 str. Ljubljana.

\section{RECOGNITION OF THE SLOVENIAN SOIL CLASSIFICATION TYPES}

\section{Summary}

The soil is always important and very expensive good. Possession of property - land is a measure of wealth. Providing your own food for survival has been a privilege since the dawn of times. When we trade with land properties for our participation in society, in fact we deal with land and soil as well. Also we are very well aware of land value. However, when the land together with soil comes in the hands of capital, we suddenly start to behave as we did towards water and air a few centuries ago. We do with soil as we please, soil becomes private property. The soil does not represent any value any more, only space has the price. On the other hand, we are painfully attached to soils. How much more we are willing to pay for the luxurious green belt around our residential area or even owning a private mini garden. Virtually every Slovene dreams of a house with a garden, where he is instinctively commited to one of the most primary human tasks. Food production is the preservation of the species. Showing two faces in this behavior is very surprising. If water and air were taken for granted in the past, only now their true value is recognized, the value of land has always been in our minds. We even named our planet Earth. Not Water, not Air.

Slovenia does not rank among the important agricultural countries. But recently we hear more and more about self-supply and self-sufficiency, particularly in relation to all the negative trends from climate changes, fossil fuel prices rising and urban sprawl.

For the geographer it is necessary to know the landscape around him and that includes soils and vegetation. That allows him to answer many questions about the status of the 
landscape and its processes. However, direct study of soils and plants in the field is extremely time-consuming, physically challenging, technically and financially demanding. Often we encounter a dilemma, what do we see in the excavated soil pit and how can all this information be synthesized in one meaningful whole, which we call a soil type.

Classification is organizing in groups according to the same or similar properties. Classification is, to a certain degree, a simplification, which reduces the amount data. Objects of classification are put in a system, which is easier for us to understand. First soil classifications are at least as old as the agriculture. Firstly, man has divided soils into two groups: fertile and non-fertile. This means appropriate and inappropriate for agricultural production. Slowly man began to use the visible characteristics, such as colour (chernozem, greysol, kastanozem...), later other soil properties (acidic, sandy, shallow, heavy ...), vegetation (tundra, forest, steppe, prairie...) or climate (tropics, Mediterranean, mountain ...).

Slovenia still does not have its own official soil classification, but we use a modification of the old Yugoslavian, which is adopted from German classification.

Basic soil unit in Slovene classification is soil type. Soil type is a genetic formation, with typical sequence of genetic horizons that form a profile. Slovene soil classification consists of 4 sets that are further divided into classes and those furthermore into types. A brief description is given about all sets, classes and types which include: differentiating soil properties, typical parent material and surface types, prevailing vegetation and extent of soil type in Slovenia. At the end, we provided a simple key to enable non-experts to determine soil type in the field without using high-tech equipment and laboratory analysis. It is based on a series of yes/no questions which lead you to the correct soil type.

At the end, a list of most common and easily recognized indicator plants is given that have narrow adaptation to light, heat, climate type, soil moisture, soil $\mathrm{pH}$ value and nitrogen content. Recognition of these plants in the field can help with determination of landscape characteristics and soil properties.

(Translated by the author) 